\title{
WWW の有用性について
}

国立健康 · 栄責研究所母子健康 · 栄養部

廣田晃一

はじめに

バベルの塔が崩れたかのような情報の混乱が起こっ ている。ワールド・ワイド・ウェッブ (WWW) の 開発はインターネット上に扔ける爆発的な情報量の 増加をもたらしたが，そのためにかえって望んだ情 報が見つけ出せないという弊害も生み出した。実際 WWW 上には，種々のレベルの情報が混在してお りしかもあらゆる国の言葉で書かれている。

これらの情報を有效に活用することは，栄養学研 究者にとって，はかりしれない利点をもたらすと思 われるが，現時点では多くの問題があることもまた 事実である。本稿では, これらの問題点を明らかに するとともに, 今後の改善策について考察する。

\section{WWW の仕組みと検索サービスの問題点}

WWWに載っている索引化可能な情報の総量は 現在既に 8 億ページ，6テラバイト（約 64 億字） にも達すると試算されている1”。しかし, 最大の検 索エンジンでもその $16 \%$ が検索可能になっている にすぎないともいわれ，その全貌を見極めるのは容 易ではない。

この急激な発展の一因は, WWW が一部の専門 家に独占されない極めて容易な記述言語（Hyper

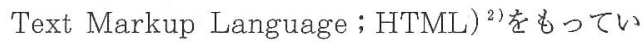

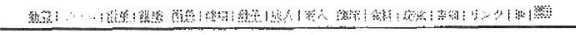

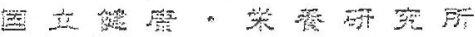

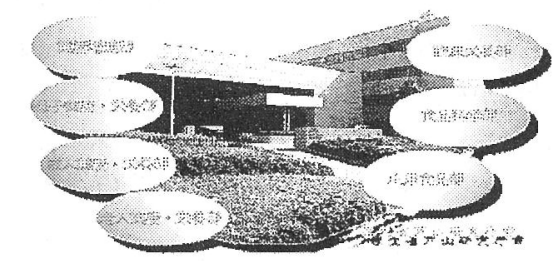

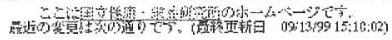

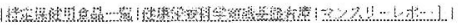
以E

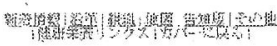

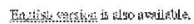

図 1 国立健康・栄養研究所ホームページ (http://www.nih.go.jp/eiken/index-j.html)
たことである。当初，HTML は簡単な見出しを付 けたり，画像を載せたりすることしかできず，表組 みさえも困難な極めてプリミティブな言語であった が、このことが幸いして，今までワープロしか触っ たことのなかったコンピュー夕初心者にも容易に扱 うことができた。これに加えて，それまでの類似の プロトコル（ネットワーク上の情報通信に使う約束 事をまとめたもの。WWW は hypertext transfer protocol； httpを用いて実際の通信が行われる) では許容していなかった個人のディレクトリ（サー バ上の登録された個人が自由にファイルを置けるハー ドディスク上のスペース）への直接の無名アクセス (パスワードが不要) が可能になる仕組みを組み込 むことによって，事実上ネットワークに繋がれたコ ンピュータにアタセス権をもつ全ての個人から不特 定多数への情報発信の可能性が開かれた（図 1 は著 者の研究所のWWW サイト)。

このような自由度の高さからくる情報の混乱は当 初加予想されて招り，早くから学術文献における 抄録誌（2 次文献誌）の役割をもつYahooのよう なディレタトリサービス（どこにどのような情報が あるかを人手で整理して提供するもの）が人気を集 めていた。また，現在の検索サイトの主流である， 自動化プログラム（ロボット）によるWWW上の 情報の自動収集・索引化も行われるようになった。

WWW はもともとリンクの形で文書間の相互参 照を行うための仕組みであったことから，Yahoo のようなディレクトリサービスは理にかなったもの であり，特定の主題に限ったものなら，個人レベル からもっと組織的なものまで，時には 1 次情報と同 じくらい提供されたが，WWW 上の情報が印刷物 のように残る情報ではないために不断のアップデー トが必要であり，また情報の選別が必要であるため， 爆発的に增加する情報量に対処しきれずに今に至っ ている。これに対して，ロボットを用いて情報収集 を行う検索エンジンは，情報に含まれる単語を主と して索引化して提供するため，コンピュー夕に対す る一定の素養と、コンピュータパワーそのものが必 要で, ディレタトリサービスのように気軽に誰もが 提供できるものではなかったが，なによりも爆発的 
表 1 対象者の属性

\begin{tabular}{l}
\hline 1. 学術雑誌の論文, 手紙, ニュースなど及び学術書籍 \\
2. 雑誌, 書籍以外の研究成果の公表 (学会発表などの再録も含む) \\
3. WHO, 厚生省, 学会など関連団体の発表など \\
4. 栄養計算, 基礎デー夕など研究に必要な情報を提供してくれるもの \\
5. 専門語辞典, 関連機関リスト, 関連研究者リストなど \\
6. 新聞, 一般雑誌の科学記事 (啓蒙記事を含まない) \\
7. 解説, 啓蒙的な文章 (新聞, 一般雑誌記事を含む) \\
\hline
\end{tabular}

表 2 「糖尿病」の検索結果と有用ホームページ (HP) の件数

\begin{tabular}{lcrcc}
\hline 国名 & 検索サービス & 検索結果 (件) & 有用HP (件) & $\%$ \\
\hline 日本 & 31 & 96,991 & 134 & 0.138 \\
アメリカ & 17 & $1,185,601$ & 248 & 0.021 \\
フランス & 17 & 10,111 & 62 & 0.613 \\
\hline
\end{tabular}

に増加する情報量に対処可能であったため, 現在も WWW 上の情報検索の主流を占めている。

しかし，上述のように検索ロボットによる情報収 集も既に限界に達しており，しかも，索引化された 情報には全く無意味に思える重複が検索結果にみら れるなどディレクトリサービス以上に無駄が多い。

WWW の基盤となっているインターネット上の コンピュータは固有のアドレスを必要とし，その数 にも上限（43 億台弱。WWWサーバの実数は現実 にはもっと少ない）があることから，その全てを自 動的に検索・索引化する検索ロボットと実際の検索 を行う検索エンジンを運用することは理論上不可能 ではない。しかし，現実にはこれを運用するための コンピュータの能力と検索サービス会社の資本力に 限界がある。

また，たとえそれが現在可能であったとしても， 検索ロボットは WWW に含まれる多様なレベルの 玉石混交の情報を選り分ける「眼」をもっていない という問題がある。ある分野に不案内な個人が参考 書を頼りに書いた文章と, 専門研究者が何年にもわ たって調査・実験を行った結果を記述した文章を同 列に扱っても，あまり意味のあることとは思われな いが，検索サービスはこれをWWW，上の情報とい う意味で同列に扱い，これらを区別して検索するこ とはできない。せいぜいできるのは大学の公的 WWW サイトにあれば信頼性があり，民間のプロ バイダの WWW サイトにあれば信頼性がないとい うような判断を下し，両者を分けて検索する（これ はサイトの名称から可能である) ことだが，いうま
でもなく, 在野の個人がいつも信頼できない素人と いうわけではないのである。

\section{2. 検索サービスを用いた情報収集の検討}

検索サービスを用いた情報の検索は実際に，それ ほど問題のあるものなのだろうか。「糖尿病」(diabetes diabète) という単一のキーワードを用いて, 既存の検索サービスによる検索を行ってみた。調査 は, 国立健康・栄養研究所のコンピュー夕を用いて 平成 10 年 4 月から 11 月にかけて行った。

ホームページ (HP) と呼ばれる長さ不定のファ イルの集合体が WWW を構成する主たる情報群で あるが, 今 HP の内容を主として栄養学研究者に とっての有用性から分類すると表 1 のようになる。 これらのうち，1５の情報 (専門情報) が研究上 最も重要で, $6 \sim 7$ の情報 (一般有用情報) が次に 重要であると思われる。ところが, 既存の検索エン ジンでは, この 2 つを分けて検索する方法もそれ以 外の情報から区別する方法も確立されていない。そ こで，筆者らは検索結果のうち，アクセス可能な全 ての HP に実際にアクセスし， 1 ～７情報の提 供を行う HP のみを有用 HP として選別した。

日本国内の検索サービスは, 調查の時点（平成 10 年 11 月 20 日）では 31 あり, 検索結果を単純に 足し合わせた総数は 96,991 件であった。ただし， これはサービス間の重複を考慮していないので, 実 数はもっと少なくなると予想される。この検索結果 からアクセス可能な全ての HP にアクセスし， 134 件を有用 HP として選別した。同様にアメリカ及 
びフランスについて, 各々の国内にある複数の検索 サービスにアクセスした結果を表 2 にまとめた。い ずれの国においても, 検索サービスの結果, 総数と 実際の有用 HP との間には大きな隔たりが認めら れた。

アメリカのみならず日本とフランスにおいても各々 の国語で書かれた有用 HP が, ともにかなりの割 合で見つかったことは興味深い。結果には示さなかっ たが, ドイッ, スペイン, イタリアといった国々に おいても, 既に日本と同様に各国語による HP が 一般的となっている。実際, 有用 HP といっても, 1〜 5 に属する専門性のある有用サイトは（国内で は）極めて限られているので, 英語圈の情報だけを （日本語に加えて）考慮していれば十分なのかもし れないが, 例えば厚生省の発表資料がほとんど日本 語だけで提供されている実状を考えると, 各国の英 語に翻訳されない情報を全て無視して差し支えない とも思われない（研究分野によって異なるだろう）。 もちろんその言語を読めなければ意味をなさないが, 各種の翻訳ソフトや翻訳サービスも一般化してきて いる現在, あるキーワードによって, 各言語ごとに 適切な訳語で検索が行われ, その結果が使用者の言 語で返ってくるような検索サービスがおそらく今後 数年間のうちに現れる可能性はある。

次に, 国内の有用 HP に限って, 更に内容の専 門性（専門情報, 一般有用情報）によって分類整理 したところ, わずかに 18 件のみが論文や学会発表 予稿のような有用な専門情報 HP であり，それ以 外は一般向けの平易な解説記事などであった。そこ で, 18 件の情報を実際に検索サービスによってど の程度検索できるのかを知るために，もう一度国内 31 の検索サービス全てについて, 検索結果の3ペー ジ目までにこの 18 件がどのくらいの割合で出現す るかを調べたところ，3.3１0\%という結果であっ た。検索サービスの検索結果はページ当たり通常 $10 \sim 20$ 件であり, 従って, 30〜60 件の情報にアク セスして 1 6 件の専門性の高い有用 HP が見つか るということであり, 極めて効率が悪いといわざる を得ない。また，3ページ目までのアクセスでは， 全ての検索サービスを使用しても，18 件全ての専 門情報を知ることはできなかった。

もちろん今回の調查で行ったように検索結果の全 てに可能な限りアクセスしていけば, いつかは目指 す情報に行き当たるかもしれないが，キーワードが 「糖尿病」というような人口に膾多した単語であれ
ばあるほど, 何万, 何十万という検索結果が返って くることになる。実際にそれら全てにアクセスする ことは検索エンジンの制限もあって不可能である。

そうかといって, 絞り込み検索を行うにしても, 内容の専門性というような観点に基づいた絞り込み は難しく，一般的でない特定の専門用語の含まれる もの，というふうにしか限定していけず，これでは 「糖尿病に関連する研究者にとって新しい知見全て」 を 1 回の検索で探し出すことはできない（ただし， 検索サービスには各々特徴があり, ひとくくりに論 じることに問題がないわけではない)。また，この 方法では特定の用語そのものを使用していない情報 にはアクセスできず，かなりの情報を取りこぼして しまう可能性が大きい。

無料という点では検索サービスと同様のアメリカ 国立医学図書館の文献検索システム (MEDLINE) では, キーワードの階層化により, より効果的に限 定された主題に関する文献のリストを得ることがで きる。この方式も実際には完全無欠とはいえないが, （対象が異なるとはいえ）検索サービスょりはるか に容易にまた確実に目指す情報に到達できる。しか し, この方法を WWW 上の 8 億ページの情報に適 用するのは現実的ではないし，そもそも，その 8 億 ページ全てが同列に扱われることこそが最大の問題 なのであり（MEDLINEでは限定的にしか実現さ れていない英語以外の情報も膨大に存在している）, その結果, 種々の技巧をこらして検索サービスを活 用しても, 図書館で限られた学術雑誌を何冊か読む 以上の情報がみつけられるかどうかも疑わしいとい う, はなはだ逆説的な事態にさえなっているのであ る。

\section{3. 栄養学関係雑誌のサイト}

上記の結果は，一般検索サービスを用いることを 前提にしたものであった。前節の最後に触れた文献 検索システムである MEDLINE は, いくつかの無 料の HPによって, 現在では自由に検索が可能 (PubMed, GratefulMedなど)である3)。また， 学術雑誌自体も順次 WWW 上に公開されるように なってきており，中には無料で論文全文や抄録が読 めるものもある。従って, 現在では図書館に学術雑 誌を読みに行くようにWWW を利用することも可 能なのである。ただし, 全ての学術雑誌が WWW で情報を公開しているわけではないことと, 公開し ていても有料であるものが多いことから, 図書館と 
全く同じというわけにはいかない。

問題なのは, 雑誌ごとの検索はできても, 複数の 雑誌にまたがる検索は, 結局 MEDLINE に収録さ れるのを待つしかないということである。現時点で は旧来の（インターネットに依存しない）サービス に付随する商業的な面を無視することはできず，将 来の改善を待つしかないのかもしれないが, インター ネットへの依存性が高まりつつある現在, 早急な改 善が望まれるところである（栄養学関連の学術雑誌 のWWW でのサービスの現状については, 少し古 くなったが, Brownの報告市がある)。

また, これらはあくまでも従来の英語圈の学術雑 誌を中心とした情報体系についてであり，それ以外 の WWW 上の（特にそこにしかない）情報は対象 になっていない。

\section{4. 将来の展望}

WWW は現在もなお急速な発展を続けている。 彫刻や陶器などの立体物, あるいは匂いなどの既存 のコンピュータでの再現が不十分なもの以外は早晚 全ての情報が WWW 上に載ると考えても間違いな いだろう。これは結局 500 年前に発明された印刷術 の辿った道を拡大再生産しているようなものである。 ということは，こうした情報の多くもまた古紙回収 場に積まれたメートルいくらの紙くず同然になる可 能性があるということである。しかし，せっかく貴 重な時間を使って仕上げた文章やそ̧の他の情報が無 䭾になることを望む人はいない。利用する側にとっ ても無䭾な時間は使いたくないのが道理である。

前節で述べたように，既存の文献検索サービス HP や学術雑誌 HP にアクセスすることによって, 従来図書館に行かなければできなかった文献検索が 机の上から自由にできるようになり，英語を主体と した文献の抄録だけでも容易に無料で読めるように なってきているのは, 研究の効率化という面で極め て大きな WWW の恩恵といえる（以前からオンラ インの文献検索は可能ではあったが，そのためには 事前登録や煩雑な命令語を学習し, 更に高い料金を 払わなければならなかった)。こうした類のサービ スだけを用いて，他の情報は無視してしまうのが, 現時点では研究者にとって最も効率のよい WWW の利用である。実際にそう割り切って使っている研 究者は筆者の周りにも多い。しかし，インターネッ トの利点は決してそこだけにとどまるものではない。 WWW は印刷技術の単なる焼き直しなのではない。
それは，マルチメディア情報の授受を世界中どこに いてもリアルタイムに実現するだけでなく，誰もが それを容易に双方向に行えるようにする仕組みなの であり，それによって誰もが自らの情報を直接世界 中に発信することができるようになったのである。 既存の文献検索サービスや出版社による情報発信は, あくまでもその「誰もが」の一部なのであって決し て「全て」ではない。

その一例として, 最近では徐々に学会の予稿集を 学会が自らのサイトで公開したり, 研究者自身が個 人的に自らのサイトに公開（これは著作権上あるい は問題があるかもしれない）したりし始めているこ とが挙げられる。確かにこうした形の情報公開には, 現時点ではまだまだ問題があるのも事実であろう。 WWW にしか公開されない情報は，そのことだけ で学術的な価值が低いとみなされる危険性があるこ とも否めない。また，たとえ公開したとしても， MEDLINE などの検索対象となる可能性も少ない。 MEDLINEなどで検索できないということは，現 時点では一般検索サービスに頼るしかないというこ とだが，上述のように検索サービスでは有用 $\mathrm{HP}$ を探すだけでも困難であり，その中から更に自分の 必要とする情報を見つけるのはほとんど至難の業で ある。

またここには記述言語の問題もある。科学の世 界では英語が事実上の公用語となっているが, 国内 の学会では日本語と英語の双方が用いられ, 実際に はほとんど全てが日本語で行われる。当然予稿集も ほとんど日本語である。日本人にはこのほうが楽で あるが, 英米の研究者にとっては日本語で書かれた HP はそのままでは表示させることさえ困難である。 これでは WWW 上に日本語で書かれた情報を公開 しても，事実上英語が支配する世界ではあまり意味 がないということになってしまう。しかし，全てを 英語で書けというのでは無謀すぎるだろう。これら は，情報発信する側にとってはもちろんのこと， WWW に印刷媒体以上の可能性を期待している利 用する側, ひいては研究者全体にとっても頭の痛い 問題である。単にインターネットの技術上の問題に とどまらず, 研究成果の公表自体に対する考え方の 変更をも余儀なくされるからである。

ここでは技術的な可能性だけを検討することにす るが, まず, 前者の問題は, 学術書が一般書とは区 別されて流通しているように, 栄養学なら栄養学に 特化した検索サービスが提供されることで幾分かは 
解決されるであろう（例えば手前味噌になるが http : //humpty.nih.go.jp/)。しかし, 検索ロボッ トあるいは検索エンジンにそれが栄養学専門 HP であることを知らせることが困難であるからこそ, なかなか有用 HP に行き着けないという問題が起 こっているのであることは上述したとおりである。 これは実は以下に述べる方法で解決可能なのだが, 手間のかかることと取り決めが何もない現状で個人 が行っても効果が少ないということからあまり利用 されていない。

少し専門的な話になるが，HPを記述する HTML にはからくりがあり, 実際にHP のソース を見ると分かるが，〈Meta Keyword=“nutrition”〉のような記述で, HP の内容や使用した $\mathrm{HP}$ 作成ソフトの名称を記述しておける。このメタ . タグを利用することで, HP の内容についての細か い分類, キーワード, 作成日, バージョン情報など をブラウザの画面上からは見えないように書いてお けるのである。ブラウザはこの部分は通常ほとんど 無視してしまうようになっているが, 検索ロボット はこの部分も解析するので, 検索サービスの利用者 はこれを利用することができる。このメタ・タグの 利用を推進しようという動きはD Dublin Core （http：//purl.org/DC/）のように英語圏ではか なり以前からあったが, これが効果を発揮するため には, 通常の文献検索と同様, 項目や用語の統一が 必要であってかなり煩雑な感があるのは否めない。 これの発展形でもあるXML ともども, これから の普及を待つというところだが, そのためには学会 などによる統一規制の成文化がぜひとも必要である と思う。

後者の言語の問題については, 既に述べたように, コンピュータ上における自動翻訳が真に実用レベル に達することで自然に解消されると思われるが, そ れがいつのことなのか少々心もとない気もする。こ れよりも容易に実現可能と思われるのは, 検索に用 いた単語あるいは文を検索時に各国語に翻訳して検 索してくれる仕組みである。日本語で日本語と英語 を同時に検索してくれるサービスは既にあるし，お そらくその他の言語と英語のものもあるのではない だろうか。これで検索結果の見出しだけでも翻訳さ れていればWWW 上の言語の壁はかなり低くなる のではないだろうか。実際にそれら外国の HP を 読むためにはその言語を知っている必要があるとし ても，関係のあることが分かっていれば意欲もわい
てくる。しかし，そのためには検索サービスの精度 向上も同時になされる必要があることはいうまでも ない。

\section{まとめ}

WWW は, 栄養学研究者にとって現状でもそれ なりに便利なツールとして手放せないものになって いるが, 潜在的な可能性からいって, 従来には考え られなかったグローバルな情報授受の手段として今 後ますます発展することが期待される。しかし，そ のためにはいくつかの問題を抱えており，その主た るものは, 情報検索サービスの効率の悪さと言語の 壁である。これらは栄養学に限った問題ではないが, 栄養学が食文化という人間の極めて人間的な問題を 扱い, 社会学的なアプローチも必要とされる分野で あるだけに, 特に言語の問題の解決は今後の発展に 大きく寄与し得ると思われる。

WWW 上の情報検索サービスの調查検討にご協 力いただきました昭和女子大学の釜島智美さんに感 謝いたします。

\section{文 献}

1) Lawrence, S. and Giles, C. L. : Accessibility of information on the web, Nature, 400, 107 (1999)

2) Raggett, D. and Jacobs, I. : HyperText Markup Language Home Page (1999, September 14) [WWW document] http : / / www.w3.org / MarkUp/(visited 1999, September 20)

3) National Library of Medicine : Search MEDLINE : PubMed and Internet Grateful Med (1999) [WWW document] http : //www.nlm.nih.gov/ databases / freemedl.html (visited 1999, September 20)

4) Brown, C. M. : Where to find nutritional science journals on the world wide web, J. Nutr., 127, 1527 1532 (1997) 